\title{
Groundwater Management in the 300 bce-1100ce Pre-Columbian City of Tiwanaku (Bolivia)
}

\section{Charles R Ortloff*}

CFD Consultants International Ltd., 18310 Southview Avenue, Los Gatos, CA 95033, USA

\section{Historical Background}

The ancient (300 BCE-1100 CE) city of Tiwanaku, capital of a vast South American empire, has been the subject of research starting from early $20^{\text {th }}$ century scholars and continuing to the present day [1-10]. The city, located at the southern edge of the Lake Titicaca Basin in the south-central portion of the South American Andes at an altitude of 3800-3900 masl incorporated an elite area bounded by an encompassing perimeter canal that supported temple complexes, palace architecture and a stepped-pyramid (the Akapana) designed to serve ceremonial functions and provide residential structures for Tiwanaku's rulers. Outside this center lay a vast domain of urban housing structures. An intricate network of canals acting in conjunction with the perimeter canal performed several hydrological functions: rapid ground drainage during both wet and dry seasons to promote health advantages for the city's 20,000 inhabitants; flood defense to preserve the ritual center and surrounding urban structures and, most importantly, height excursion control of the deep groundwater base underlying the site. This latter function prevented dry-out collapse of the deep aquifer underlying the city's monumental center preserving its bearing strength and limiting subsidence of foundation soils underlying massive monumental structures within the perimeter canal's boundary.

Newly discovered aerial photographs taken in the 1930s provide data to interpret the extent of, and insight into, the hydrologic function of the perimeter canal. The early photographs reveal traces of the perimeter canal's north and south arms in addition to a northsouth canal (Mollo Kontu canal A-B, Figures 1-4, 5M) intersecting the southern perimeter canal arm. The perimeter canal collected flow from adjacent canals, rainfall runoff and infiltrated rainfall seepage from the saturated, near-surface part of the aquifer (defined as the phreatic or vadose layer) as well as from the deep groundwater aquifer (as the perimeter canal depth intersected to top portion of the deep groundwater layer) to transfer water into the nearby Tiwanaku River during the rainy season to limit deep groundwater recharge. During the dry season, phreatic layer aquifer seepage plus water supplied from the intersecting Mollo Kontu canal maintained the level of the deep groundwater aquifer relatively constant while surface evaporation and recession of the near-surface phreatic aquifer served to rapidly dry the ground surface promoting health and livability benefits for city inhabitants. The design intent of the builders of the perimeter canal envisioned control of the deep groundwater level through both wet and dry seasons to maintain the physical integrity of monumental structures. Given a stable upper boundary of the deep groundwater table throughout the year, physical strength properties of foundation soils were maintained, limiting structural distortion and settling of the massive platforms of the Sunken Temple, Kalasasaya, and Akapana within the ceremonial center. Thus, beyond the perimeter canal's role in creating a ritual and social boundary between the ceremonial center and secular residential city districts, its engineering design contributed to long-term structural stability of monuments, promoted rapid runoff water removal and rapid phreatic zone drying leading to beneficial living conditions for city residents throughout wet and dry seasons.

\section{Tiwanaku Hydraulic Analysis}

To illustrate the perimeter canal's hydrologic functions, multiple data assemblages used to construct a computational fluid dynamics (CFD) hydrological model (Figure 5) include results of archaeological mapping and excavation [11-15], Google Earth imagery and aerial photos taken over the site of Tiwanaku. These recently discovered photographs reveal the site decades before urbanization and monumental reconstruction began to transform it into a tourist destination and were taken at a time of year when many features held water, thus providing a clear view of Tiwanaku's hydrological features. From these photographs, the outline of the perimeter canal is shown in Figure 2 as the dark encircling boundary to the ceremonial center. The east canal arm averages 4-5 $\mathrm{m}$ deep and ranges $18-28 \mathrm{~m}$ in top width. Subterranean canals originating from the perimeter canal's south arm were vital drainage conduits for Tiwanaku's monumental and elite residential structures [15]. Since the south arm of the perimeter canal is shallower in depth than the north arm as determined by ground contour measurements [16], a fraction of the water that accumulated in this arm drained down-slope through the perimeter canal's east and west arms toward the Tiwanaku River while a portion of accumulated water in the south arm flowed into the subterranean channels (Figure 4) underlying the ceremonial center. Given the two degree declination slope of the subterranean channels toward the north, water accumulated in the perimeter canal's bottom during the wet season (and to a lesser degree in the dry season) provided flushing water for the Putuni palace's waste removal/drainage facilities. The north canal section is vital for understanding the perimeter canal's hydrological function. North of Tiwanaku's northwest monumental complex, the shallow alluvial plain drops sharply several meters down toward the Tiwanaku River's marshy floodplain. One portion of the east arm of the canal turns westward and disappears into the marsh (Figures 1 and $5 \mathrm{C}$ ) while another canal (C) continues northward toward the river. One portion of the west arm turns sharply to the east and ultimately disappears into the marsh north of the Kalasasaya (Figure 5) while an ancillary arm continues northeast toward the river. The north portion of the perimeter canal thus divided into several branch canals that intersected the marshy floodplain and drained accumulated water from the north arm of the perimeter canal. Water not directly shunted to the Tiwanaku River through canal C (Figure 5) resided in a

*Corresponding author: Charles R Ortloff, CFD Consultants International Ltd. 18310 South view Avenue, Los Gatos, CA 95033, USA, Tel: 408-353-2308; E-mail: ortloff5@aol.com

Received March 06, 2014; Accepted April 11, 2014; Published April 15, 2014

Citation: Ortloff CR (2014) Groundwater Management in the 300 bce-1100ce PreColumbian City of Tiwanaku (Bolivia). Hydrol Current Res 5: 168. doi:10.4172/21577587.1000168

Copyright: @ 2014 Calvo AR, et al. This is an open-access article distributed under the terms of the Creative Commons Attribution License, which permits unrestricted use, distribution, and reproduction in any medium, provided the original author and source are credited. 
Citation: Ortloff CR (2014) Groundwater Management in the 300 bce-1100ce Pre-Columbian City of Tiwanaku (Bolivia). Hydrol Current Res 5: 168. doi:10.4172/2157-7587.1000168

saturated (near-surface) phreatic layer of the aquifer that subsequently drained water in the floodplain's aquifer into the Tiwanaku River. The floodplain area served as a productive agricultural system for the urban center by utilizing its available water surplus.

\section{The Perimeter Canal as Key Feature in an Urban Hydrological Network}

Where the groundwater surface emerged from depressed areas, springs were formed. Several canals in the southern portion of Tiwanaku were engineered to utilize this canal water input (generalized surface feature model, Figure 5); the westernmost Choquepacha area's canal $[6,9,17]$ derived from a natural spring on a bluff just southwest of Pumapunku. The spring was fitted with a basin that included several incised canal stones carved to convey water [5]. Combined with the output of an adjacent stream that drained a marshy area of the terreplein, the Choquepacha area supported extensive terrain amenable to pastoral grazing and farming immediately to the west of the Tiwanaku urban area [17].

Other features relate directly to the hydrological function of the perimeter canal. The first feature is a north-south (Mollo Kontu) canal that supplied water from springs originating from the southwest portion of the site near the Pumapunku complex into the southwest portion of the perimeter canal (Figures 1-3; canal S-M, Figure 5). This canal is visible in aerial photographs and has not been previously identified as a hydraulic feature intersecting the perimeter canal. The second feature is an interlinked cluster of sunken basins, or qochas, that occupy the southeast or Mollo Kontu portion of the site (Figures $1(\mathrm{~K}), 5(\mathrm{~K}))$. Qochas are pits excavated into the phreatic aquifer layer that capture and store rainwater and serve to expand planting surfaces and pasturage while creating micro-lacustrine environments that attracted waterfowl [18-20]. The aerial photos depict a series of canals dendritically linking some of the qochas and ultimately pointing towards the Akapana East canal (L, Figure 5) that drained into the east arm of the perimeter canal. The third major feature is a long, narrow, outer canal (J) that bounded the east side of

Tiwanaku (Figures 1,2 and 5). While the overall role of this canal is unclear, its southern portion is straight and follows an alignment that mirrors that of the Pumapunku complex to the west. Its northern

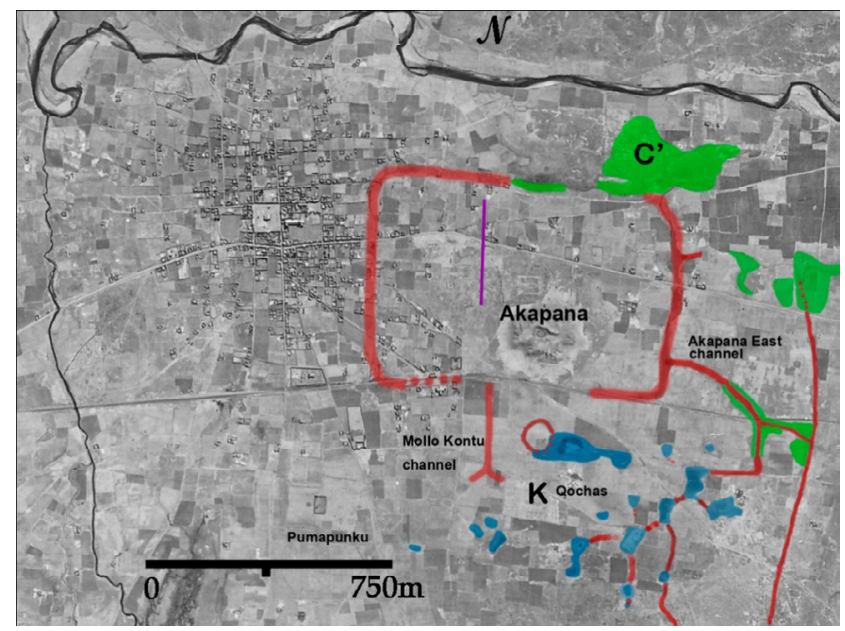

Figure 1: View of the perimeter canal surrounding the ceremonial core of Tiwanaku indicating the intersecting MolloKontu canal, qocha regions and the Tiwanaku River to the north.

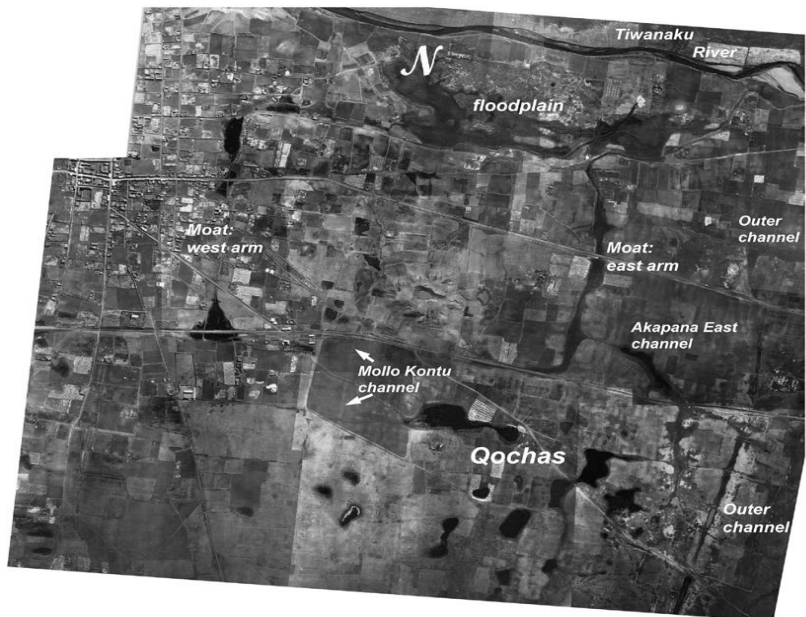

Figure 2: Composite image of the aerial photos noting key hydrological features.
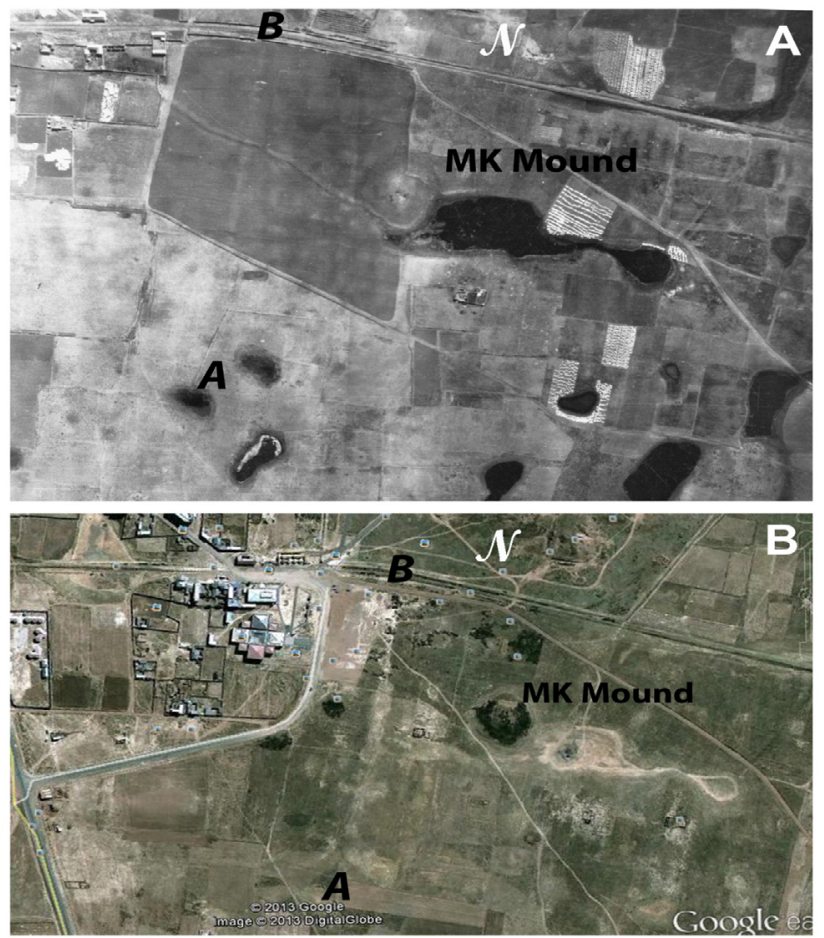

Figure 3: The MolloKontu canal (M) as depicted A-B in the aerial photos and Google Earth satellite imagery.

portion shifts course and bounds the east edge of the site following an orientation similar to that of the east arm of the perimeter canal. The east canal (L, Figure 5) links with the perimeter canal by connector canal I indicating that the outer canal was part of an encompassing urban hydraulic network. The areas immediately east of the canal contain Tiwanaku's easternmost residential sectors and include Ch'iji Jawira, a barrio of ceramic producers that depended on a constant water supply $[12,20]$. Immediately east of the Ch'iji Jawira sector is a low brackish marsh; from this marsh, the outer canal (J) likely provided 
Citation: Ortloff CR (2014) Groundwater Management in the 300 bce-1100ce Pre-Columbian City of Tiwanaku (Bolivia). Hydrol Current Res 5: 168. doi:10.4172/2157-7587.1000168

Page 3 of 7

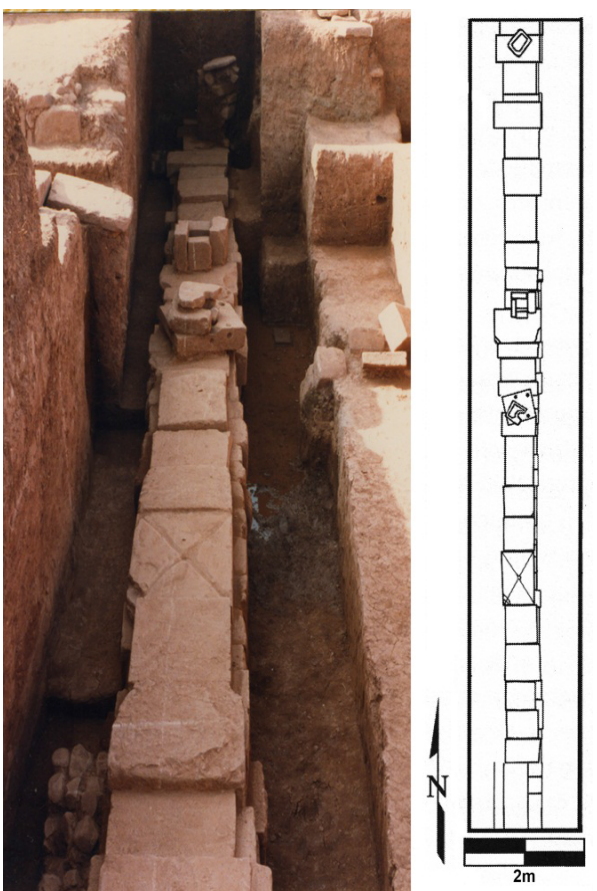

Figure 4: Photo and plan view of the excavated portion of the subterranean Putuni channel (P). Image from Couture and Sampeck, 2003:235.

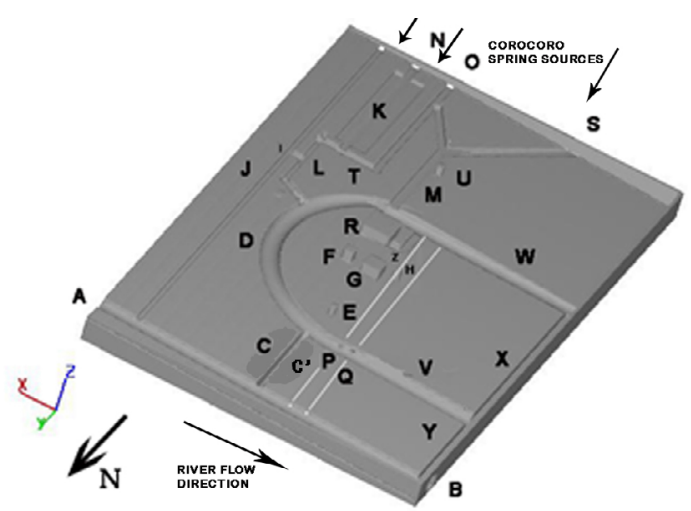

Figure 5: Representative CFD porous medium model of hydrological and architectural features of the Tiwanaku urban center identified by in-text letters. Model is a best-estimate representation of the original site geometryfrom aerial photos, historical sources and ground survey.

fresh water from springs for Tiwanaku's easternmost residential sectors and drainage of excessive canal flow during the rainy season.

The east and west arms of the perimeter canal directed water around the northeast monumental complex of Tiwanaku toward the Tiwanaku River to the north (Figures 1 and 5). As noted, at least two branches of the perimeter canal north of the Tiwanaku monumental center drained into a marshy floodplain C'. The C' floodplain was an integral part of Tiwanaku's larger hydraulic network and served as an area that facilitated drainage of both groundwater and rainwater runoff during rainy season peaks. Intricate surface canals and subterranean stoneslab constructed canals (Figures 4 and 5) provided additional drainage within the area bounded by the perimeter canal. The elaboration of surface canals on the interior floor of the Sunken Temple and areas just outside the Kalasasaya platform [21] indicate a drainage connection to either (or both) the perimeter canal and the subterranean channel $\mathrm{P}$ (Figure 5). The Akapana pyramid (R, Figure 5) incorporated an intricate, stone-lined canal network that routed water circuitously from the uppermost down through successively lower platforms and finally out through several portals in its basal terrace [22] to several open surface basins draining into vertical pipes (and/or the perimeter canal) that conveyed water into the large, deeply buried channels $\mathrm{P}$ and $\mathrm{Q}$ (Figure 5) to the east and west of the structure [3]. The subterranean canals conducted flushing water to remove human waste from the Putini residential compound toward the northern arm of the perimeter canal for conveyance to the Tiwanaku River.

Excavations between Putuni and Kerikala complexes indicate how structures within the core articulated with Tiwanaku's subterranean drainage network. This area housed high status groups until, at approximately $\mathrm{AD} 800$, the construction of the Putuni platform repurposed the space to support recurring state-sponsored ceremonies $[6,15,23]$. Located $3.5 \mathrm{~m}$ below the current ground surface, canal $\mathrm{P}$ (Figures 4 and 5) consisted of sandstone slab masonry with vertical standing slabs approximately one meter high and horizontal slabs about 0.8-0.9 $\mathrm{m}$ across $[1,7,15,21]$. Several vertical pipes consisting of multiple stacked, perforated stone disks conducted surface water from features within the Putini to the lower subterranean channel $\mathrm{P}$ [12]. Water from the peripheral canal's southern arm supplemented by water from canals $\mathrm{L}$ and $\mathrm{M}$ together with perimeter canal seepage water was used to flush waste water through subterranean channels $P$, $\mathrm{Q}$ located in the west portion of the monumental core.

\section{Models of Water Management at Tiwanaku}

To demonstrate conclusions related to the hydrological function of the perimeter canal, use of Computational Fluid Dynamics [24] is made for cases that address seasonal variability in water input. Case 1 considers effects existing at the termination of a long duration rainy season on Tiwanaku's canal systems and city open surface areas. The rainy season in the south-central Andean altiplano is intense and generally runs from November through March. Case 2 considers effects of limited water input from springs and aquifer seepage into the deep groundwater layer during the dry season which runs from April through October. Data from aerial photographs, Google Earth imagery, contour maps and ground survey provide the basis for the computational model (Figure 5) to demonstrate hydrological features of the perimeter canal and its encompassing hydrological network. A porous soil model (Figure 5) is used to demonstrate hydrological responses of the canal network for different water input cases. Figure 5 model's surface and subterranean features are on the same scale as Figures 1-3 and represent best-estimate $9^{\text {th }}-10^{\text {th }}$ century CE water supply and distribution network canal paths inferred from available data. The canal inlets shown (J, N, and O) are sourced by canalized Corocoro springs located south of the modeled area as are canals (S-M) leading from the Pumapunku area. Key monument architectural and hydrologic features in Figure 5 are:

A-B: the Tiwanaku River, flow direction A to B (east to west)

C: perimeter drain canal to A-B

C' the drainage and agricultural complex supplied from perimeter canal drainage path $\mathrm{C}$

\section{E: La Karaña residential complex}

F: Sunken (or Semi-subterranean) Temple

G: Kalasasaya 
Citation: Ortloff CR (2014) Groundwater Management in the 300 bce-1100ce Pre-Columbian City of Tiwanaku (Bolivia). Hydrol Current Res 5: 168. doi:10.4172/2157-7587.1000168

Page 4 of 7

\section{H: Putuni}

I: Connecting canal between canals L -K - L and J

$\mathrm{K}$ : multiple interconnected qocha region supplied by canal $\mathrm{N}$

L: Akapana East canal, which drained qocha region $\mathrm{K}$ toward perimeter canal arm $\mathrm{D}$

M: Mollo Kontu canal linking supply canals $\mathrm{O}$ and $\mathrm{S}$ to perimeter canal arm W

\section{$\mathrm{N}$ : Supply canal to qocha region $\mathrm{K}$}

O: Connecting canal to canal $\mathrm{M}$

$\mathrm{P}$ and Q: subterranean channel pair below with declination slope of two degrees to the river; channel $\mathrm{P}$ runs underneath the Putuni $\mathrm{H}$

R: Akapana seven-stepped truncated pyramid

S: branch canal to Mollo Kontu canal M

T: lateral transverse canal to L; shunt canal I to canal J and/or drain canal to perimeter canal, section D

\section{U: Mollo Kontu monument}

W-D-V-X: the depressed perimeter canal circuit around the monumental core of Tiwanaku; original depth of the canal estimated at 3-5 $\mathrm{m}$ at location $\mathrm{D}$.

Y: drainage canal from $\mathrm{V}$ to the Tiwanaku River (trace from aerial photographic source; its inclusion in the model has a minor drainage effect compared to prominent drainage features C, C' P, Q from the perimeter canal

$\mathrm{Z}$ : canal below the west side of the Akapana (R) draining toward perimeter canal segment $\mathrm{D}$.

The CFD model is composed of a porous medium aquifer representing the soil material properties through which groundwater percolates and incorporates both an east-to-west ground slope declination and a south-to-north declination observed from field measurements. Within the aquifer, groundwater percolation velocity is slow compared to surface runoff and canal water flow velocity. The momentum resistance to flow in the porous medium representation of an aquifer [24] is expressed as a vector drag term $F_{d} u$ where $F_{d}$ is the porous media drag coefficient and $u$ the velocity vector $u=q_{x} i+q_{y} j+$ $\mathrm{q}_{\mathrm{z}} \mathrm{k}$ with $\mathrm{q}_{\mathrm{x}}, \mathrm{q}_{\mathrm{y}}, \mathrm{q}_{\mathrm{z}}$ velocity components in the $\mathrm{i}, \mathrm{j}, \mathrm{k}(\mathrm{x}, \mathrm{y}, \mathrm{z})$ coordinate directions respectively (Figure 5). Porous medium permeability $\mathrm{k}$ is defined as $\mathrm{k}=\mathrm{V}_{\mathrm{f}} \mu / \rho \mathrm{Fd}$ where $\mathrm{V}_{\mathrm{f}}$ is the volume fraction (open volume between soil particles and total volume), $\mu$ the water viscosity and $\rho$ the water density. For the present analysis, $\mathrm{k}$ is on the order of $\sim 10^{-11} \mathrm{~cm}^{2}$ based upon the site soil type $[25,26]$ within the model area excepting monumental complex paved areas for which $\mathrm{k}$ is on the order of $\sim 10^{-15} \mathrm{~cm}^{2}$. For soils in the model area, $0.43<\mathrm{V}_{\mathrm{f}}<0.54$. Based on these estimates, the average drag coefficient $F_{d}$ is estimated to be $\sim 0.80$. While deviations from this value occur due to varying soil properties with depth and location, flow delivery rates from the saturated aquifer to the perimeter canal's seepage surface (defined as the exposed interior soil surface of the perimeter canal exposed to the atmosphere) will be affected but calculations nevertheless demonstrate qualitative conclusions regarding the canal's function. In the CFD model, the deep groundwater layer is composed of saturated soil and is stabilized throughout the year at $\sim 4-5 \mathrm{~m}$ below the ground surface as well probe data indicates. The phreatic saturated-aquifer zone lies above and separate from the deep aquifer for Case 1 calculations. The bottom of the perimeter canal intersects the upper reaches of the deep groundwater layer in the Figure 5 model and both the phreatic and deep groundwater layers provide seepage water into the perimeter canal together with runoff water and canal water supplied by springs south of the city. Above the deep groundwater layer an intermediate capillary fringe zone extends upward to intersect the bottom reaches of the phreatic zone; this additional water transfer occurs when the phreatic layer extends sufficiently downward to penetrate the groundwater capillary fringe zone during heavy, long duration rainy periods. For extreme cases for which rainfall is intense and of long duration, the phreatic and deep groundwater regions merge- here seepage intensifies to limit long-term recharge and height excursion of the deep aquifer. In most cases however, phreatic layer drainage and collection of runoff into the perimeter canal prevent this intersection from occurring. The shape and saturation depth of the phreatic layer is subject to change depending upon rainfall intensity, duration and soil infiltration effectiveness as well as effects of drainage water loss and surface evaporation. For Case 1 analysis, the post-rainy season phreatic layer is saturated and lies above the deep groundwater layer; excess non-infiltrated rainwater is then the source of runoff into the perimeter canal. As the dry season progresses, the phreatic layer shrinks upward toward the ground surface as surface evaporation and aquifer drainage proceeds.

\section{Case 1- post-rainy season ground saturation conditions}

Case 1 examines post-rainfall conditions typical of the end of the altiplano rainy season characterized by phreatic zone saturation and continuous water flow through canals $\mathrm{O}, \mathrm{S}, \mathrm{N}, \mathrm{M}$ and J from Corocoro springs. Aquifer seepage to the bottom of the perimeter canal from the saturated phreatic layer is transferred to perimeter canal arms $D, V$ and $\mathrm{W}$ to $\mathrm{X}-\mathrm{Y}$ and then to the Tiwanaku River (A-B in Figure 5) as all canals down-slope toward the river. Additional seepage occurs from the top reaches of the deep groundwater layer into the perimeter canal. Water from the perimeter canal's east and west arms was ultimately conducted to the Tiwanaku River through the $\mathrm{C}$ canal branch and seepage from the C' area. Water arriving into inlet $\mathrm{N}$ is conducted by canals $\mathrm{K}$ and L into either (or both) canals D and then from I to J. A summary of rainy season water inflows/outflows from a representative section of the perimeter canal is shown. Numerical solutions [24] of equations governing saturated/unsaturated aquifer and surface/subterranean canal flows give a total picture of transient water transfers to/from the perimeter canal from seepage and canal flows given estimates of their flow rates based on supply spring flow rates. Given Case 1 post-rainy season conditions, surface runoff has been largely collected into the perimeter canal and transferred to the river; further water transfer to the bottom of the perimeter canal is from aquifer seepage and adjacent canal input- this water is rapidly discharged into the Tiwanaku River. Results shown in Figures 6-8 shows a time progression of water seepage from the perimeter canal's open surface area and progressive surface drying as the phreatic layer deflects downward due to drainage into the perimeter canal. Here the highest seepage water outflow rate occurs toward the phreatic layer's bottom reaches due to higher hydrostatic pressure as indicated by highest values of the fluid fraction ff. Fluid fraction $\mathrm{ff}$ is defined as the distributed water volume within the porous soil volume interstices where $\mathrm{ff}=1$ represents saturated soil conditions (total infilling of open space within a porous unit volume) and $\mathrm{ff}=$ 0 represents no water present in porous volume interstices (dry soil conditions). Intermediate $0<\mathrm{ff}<1$ values indicate variable amounts of water content in the porous soil- otherwise considered as distributed moisture within the soil. 
Citation: Ortloff CR (2014) Groundwater Management in the 300 bce-1100ce Pre-Columbian City of Tiwanaku (Bolivia). Hydrol Current Res 5: 168. doi:10.4172/2157-7587.1000168

For saturated aquifer conditions and isotropic porosity and permeability, the lateral $(\mathrm{x})$ aquifer specific discharge is $q_{X}=-(k / \mu)\left(\partial_{\mathrm{p}} / \partial_{\mathrm{X}}+\rho \mathrm{g} \partial_{Z} / \partial_{X}\right)$ where $\mathrm{p}$ the water pore pressure, $\mathrm{g}$ the gravitational constant and $\mathrm{z}$ is the vertical distance measured from a reference ground surface position. The last term represents a lateral water velocity increase from gravitational forces in the vertical $\mathrm{z}$ direction; from the Darcy equation [25], the $\mathrm{z}$-direction pressure gradient increases with soil depth and increases the water seepage rate with depth measured from the ground surface. The effect of gravitational force exceeds surface tension retention effects on percolation flow through the porous aquifer for large $V_{f}$ values and is not considered in the CFD calculations. At the perimeter canal's exposed-to-atmosphere seepage surface, the horizontal pressure gradient is yet higher further increasing the water seepage outflow rate into the perimeter canal. Given the volume fraction $V_{f}$ and the fluid fraction distribution, the product represents the water volume present per unit aquifer volume. High values of this product are indicated from high water seepage concentrated toward the bottom surface of the perimeter canal (Figures 6 and 7) inducing progressive dryness (lower values of the fluid fraction) in the ground surface area bounding the perimeter canal as time progresses. Figures 6 to 8 show ground areas east of the perimeter canal saturated $(\mathrm{ff}=1)$ from infiltrated runoff and water from the watershed regions east and south of the city center. As aquifer seepage proceeds in time, surface dryness increases, augmented by surface evaporation and dryness, and is evident close to the canal boundaries as Figures 6 and 7 indicate. Rapid water removal from the perimeter canal via canals $\mathrm{C}$ and $\mathrm{X}-\mathrm{Y}$ to the Tiwanaku River largely eliminate water transfer from the phreatic aquifer to the deep groundwater layer promoting its height stabilization. The monumental core experienced limited rainfall infiltration due to extensive paving and compound roofing that promoted runoff into the perimeter canal. Water that managed to infiltrate open areas was then drained into the canal and subterranean channels $\mathrm{P}$ and Q (Figures 4, 5 and 8) which then directed water toward C' and ultimately to the Tiwanaku River through C' drainage and C, X-Y canals.

The perimeter canal depth extended to the top fringe of the deep groundwater layer (Figures $1 \& 2$ ) and helped stabilize the deep groundwater layer depth below the monumental center by continuous drainage of water from runoff, aquifer drainage and excess $\mathrm{N}, \mathrm{O}, \mathrm{S}$, $\mathrm{M}$ and I-L canal flows during the rainy season. In the dry season, continued, but reduced spring-sourced flow from canals $\mathrm{N}, \mathrm{O}, \mathrm{S}$ and $\mathrm{M}$ plus continued aquifer seepage maintained the top level groundwater

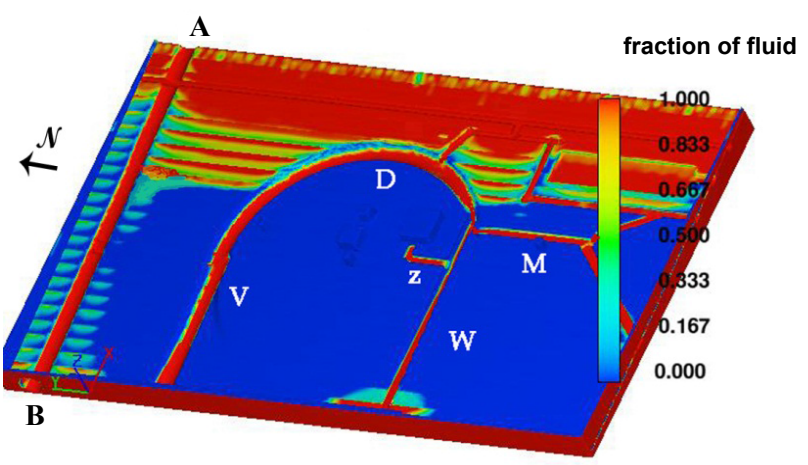

Figure 6: Case 1, post-rainy season fluid fraction results indicating water capture into the perimeter canal's bottom from the canal's east arm seepage surface.

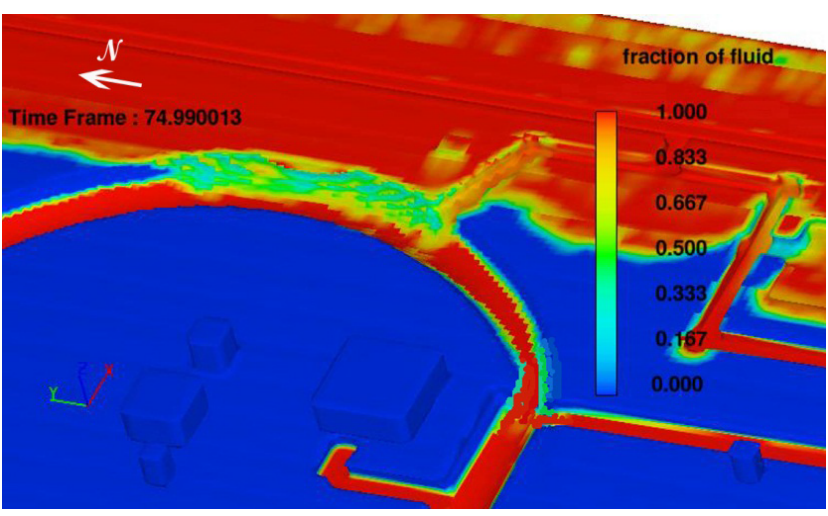

Figure 7: Later time detail of the east arm of the perimeter canal showing the seepage surface conducting water to the bottom of the canal and progressive surface drying for Case 1 conditions.

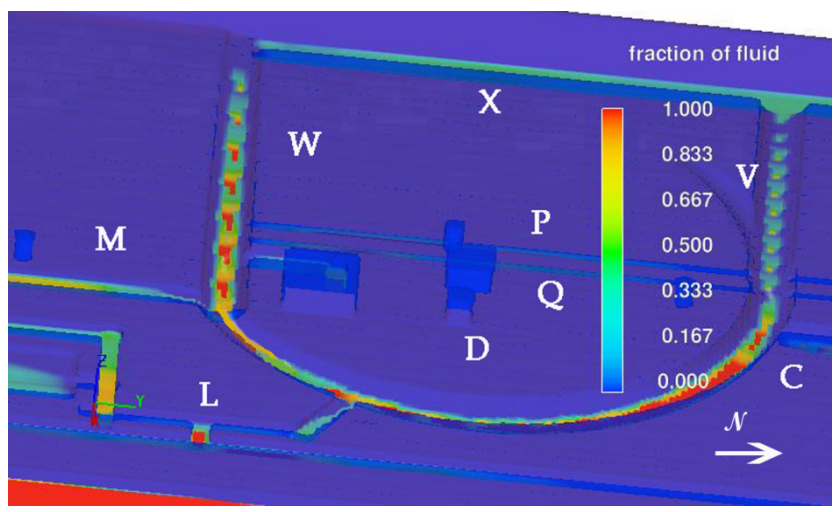

Figure 8: Case 1 Fluid fraction results showing drainage from the ceremonial center into the western arm of the perimeter canal.

height. The result was a stabilized deep groundwater height throughout the year preventing aquifer dry-out collapse and subsidence from water withdrawal from porous soil interstices. This effect maintained the soil bearing strength [26,27] and reduced foundation settling distortions of the massive Akapana structure (R) s well as other monuments by stabilizing the moisture content of foundation soil throughout wet and dry seasons. Figure 8 shows fluid fraction results at the inner face of the perimeter canal bounding the ceremonial center. Results confirm seepage was minimal from what little infiltrated rainwater existed in this largely paved and roofed area of the city and that accumulated drainage water into the perimeter canal's bottom was quickly removed by canals $\mathrm{C}$ and $\mathrm{X}-\mathrm{Y}$ to the Tiwanaku River. It shows the water transport in subterranean channels $\mathrm{P}$ and $\mathrm{Q}$. Channel P lies under the floor of the Putuni; channel Q lies at the same depth as P but $\sim 20 \mathrm{~m}$ west of P. Vertical pipes connected drainage areas in the Putuni Courtyard and Palace [15] to channel $\mathrm{P}$ with collected water directed toward the $\mathrm{V}$ arm of the perimeter canal. The $\mathrm{P}$ and $\mathrm{Q}$ subterranean channels required a regular input of flushing water from perimeter canal arm $\mathrm{W}$ to maintain residential area hygienic conditions; this was supplied by canal $\mathrm{M}$ as well as from seepage water elevated above the inlets of channels $\mathrm{P}$ and $\mathrm{Q}$. As the $\mathrm{P}, \mathrm{Q}$ channels, the $\mathrm{C}$ canal, and the perimeter canal bottom all sloped downhill toward the Tiwanaku River, flushing flow from perimeter canal arm $\mathrm{W}$ directed water and waste solids away toward the river. 
Citation: Ortloff CR (2014) Groundwater Management in the 300 bce-1100ce Pre-Columbian City of Tiwanaku (Bolivia). Hydrol Current Res 5: 168. doi:10.4172/2157-7587.1000168

Page 6 of 7

\section{Case 2- dry season initiation}

Case 2 considers the perimeter canal function under dry season conditions (zero rainfall and continuous, but limited, water supply from Corocoro springs into surface canals $\mathrm{N}, \mathrm{O}, \mathrm{S}$ and $\mathrm{M}$ ). Qocha regions $\mathrm{K}$ and C' (Figure 5) remained functional due to their depth penetration into the receding phreatic zone water level indicating agriculture and pasturage were still possible during dry season conditions. By rapid water transfer of seepage, runoff and adjacent canal water through multiple canal paths in the rainy season to the Tiwanaku River and continued aquifer seepage into the perimeter canal together with Corocoro spring-sourced canal water supply in the dry season, the deep water table remained stabilized in height year-round below and distinct from the phreatic zone aquifer and helped maintain the structural stability of ceremonial core structures. Channels $\mathrm{P}$ and $\mathrm{Q}$ indicate continued water transport and flushing activity from perimeter canal segment $\mathrm{W}$ as the dry season progressed with canal $\mathrm{M}$ providing water supply during the dry season. Figure 11 indicates limited groundwater seepage into perimeter canal arm D as spring water sources diminished in the dry season and the phreatic zone recedes from the ground surface.

\section{Conclusions}

CFD results indicate that the perimeter canal served to keep Tiwanaku's ceremonial center and the surrounding urban area relatively dry throughout the year while maintaining a constant top level of the deep groundwater zone year-round. In the rainy season, the deep groundwater table upper boundary was stabilized by runoff and aquifer drainage into the perimeter canal; in the dry season, continual seepage from the phreatic zone aquifer and canal $\mathrm{M}$ kept the deep groundwater upper boundary from subsiding. The resulting stabilization of the deep groundwater boundary prevented settling of monumental structures in the ceremonial core and originated from the perimeter canal's depth intersection of the top fringe of the deep groundwater layer. This engineering innovation originated from knowledge of groundwater manipulation previously shown as vital to sustain Tiwanaku's raised field agriculture [28]. Channels P and Q largely served the hygienic requirements of the Putuni and Kerikala structures by providing continuous flushing from perimeter canal seepage water plus canal $\mathrm{M}$ water arriving into canal arm W. Each major monumental structure maintained an intricate drainage system that simultaneously served practical and symbolic purposes as exemplified by the Akapana's elaborate drainage network that limited rainfall infiltration into its earth-fill interior to preserve its structural integrity. Canals $\mathrm{O}, \mathrm{N}$ south of the canal directed water to the qocha complex $\mathrm{K}$ for inter-city agricultural and pasturage purposes. Runoff water washed into canals $\mathrm{N}, \mathrm{O}$ and $\mathrm{S}$ exceeding their carrying capacity was diverted into canals $\mathrm{L}$, I and $\mathrm{J}$ leading to the river protecting urban regions from canal overflow flooding. In totality, the perimeter canal was the linchpin of an intricate hydraulic/hydrologic network that controlled surface and aquifer flows as rainfall amounts varied from rainy to dry seasons. Analysis of the canal's hydrological function indicates that qocha systems were an integral feature of urban Tiwanaku. Interlinked by canals fed by Corocoro springs, qocha clusters $\mathrm{K}$ and C' occupied massive portions of the city and likely supported camelid herds and caravans brought to the center during key social gatherings [9] Recent excavations in adjacent Mollo Kontu residential compounds support the hypothesis that llama and alpaca herds were important in this part of Tiwanaku [29] and were well served by K and C' qocha areas. There were other elements to rural production within Tiwanaku proper. First, raisedfield and qocha systems occupied the edges of some of the city's canals as evident from earlier photographs of the edges of canals I, J, L and C to support localized in-city agriculture. Second, the floodplain at the south edge of, and several meters below, the main portion of Tiwanaku supported an extensive cluster of integrated raised-field networks and qochas to support additional intra-city agriculture.

Prior studies focused on Tiwanaku's hinterland demonstrated an understanding of hydrologic principles to develop intensive raisedfield farming systems $[7,9]$. Present research indicates that the urban center of Tiwanaku likewise incorporated an intricate hydrological network focused on the perimeter canal that effectively managed seasonal water variations through surface canals, underground channels and aquifer drainage manipulation [30]. Tiwanaku city planners demonstrated an extraordinary level of knowledge regarding hydrologic and structural maintenance principles based upon surface and groundwater manipulation to maintain high livability standards under harsh altiplano environmental conditions. Building on prior studies of the groundwater-based raised-field systems that supported agriculture for the large population of Tiwanaku, analysis results demonstrate that knowledge of surface and groundwater flows within urban Tiwanaku merit further consideration in assessing New World engineering science.

\section{References}

1. Crequi-Montfort G (1906) Excavations of the French Scientific Mission in Tiahuanaco. Archaeological and Ethnographic it's in Bolivia, Chile and the Argentine Republic Searches. Proceedings of the 14th International Congress of Americanists. Stuttgart 2: 531-50.

2. Bandelier A (2012) The Ruins at Tiahuanaco. Proceedings of the American Antiquarian Society 21, Part 1.

3. Means PA, Ancient Civilizations of the Andes. New York: C. Scribner's Sons.

4. Bennett, Wendell C (1905-1953) Excavations at Tiahuanaco. Anthropological Papers of the American Museum of Natural History 34.

5. Posnansky A (1945) Tihuanacu: The Cradle of American Man.Augustin Publishers I-II. New York, USA.

6. Kolata AL (1993) Tiwanaku: Portrait of an Andean Civilization. Blackwell Publishers, Cambridge, UK.

7. Kolata AL, Ortloff CR (1989) Thermal Analysis of Tiwanaku Raised-Field Agriculture in the Lake Titicaca Basin of Bolivia. Journal of Archaeological Science 16: 233-263.

8. Browman DL (1997) Political Institutional Factors contributing to the Integration of the Tiwanaku State. Fundamental Issues in Archaeology: 229-243.

9. Janusek JW (2008) Ancient Tiwanaku. Cambridge University Press, New York.

10. Alexei V, Levine A(2013) Advances in Titicaca Basin Archaeology 2.UCLA: Cotsen Institute of Archaeology, University of California, Los Angeles, USA.

11. Chiji Jawira (2003) A Case of Ceramic Specialization in the Tiwankau Urban Periphery. In Tiwanaku and Its Hinterland: Archaeology and Paleoecology of an Andean Civilization 2: 296-315.

12. Janusek, JW (1999) Craft and Local Power: Embedded Specialization in Tiwanaku Cities. Latin American Antiquity 10: 107-131.

13. Janusek JW, Earnest $H$ (2009) Excavations in the Putuni: the 1988 season. In Tiwanaku and its Hinterland University of Chicago 236-46.

14. Couture N (2002) The Construction of Power: Monumental Space and an Elite Residence in Tiwanaku, Bolivia. Department of Anthropology, University of Chicago, USA.

15. Sampeck K(2003) Putuni: A History of Palace Architecture in Tiwanaku. Smithsonian Institution Press, Washington DC, USA.

16. Kolata AL (2003) Tiwanaku and Its Hinterland: Archaeology and Paleoecology of an Andean Civilization. Smithsonian Institution Press, Washington DC, USA.

17. Bruno M (1999) Sacred Springs: Preliminary Investigation of the Choquepacha Spring /Fountain, Tiwanaku, Bolivia. 
Citation: Ortloff CR (2014) Groundwater Management in the 300 bce-1100ce Pre-Columbian City of Tiwanaku (Bolivia). Hydrol Current Res 5: 168. doi:10.4172/2157-7587.1000168

18. Craig N, Aldenderfer MS, Rigsby CA, Baker PA, Blanco LF (2011) Geologic Constraints on Rain-fed Qocha Reservoir Agricultural Infrastructure, Northern Lake Titicaca Basin, Peru. Journal of Archaeological Science 38:2897-2907.

19. Denevan W (2001) Cultivated Landscapes of Native Amazonia and the Andes. Oxford University Press, UK.

20. Rivera Casanovas CS (1994) Ch'iji Jawira: Evidence on the Production of Ceramics in Tiwanaku. Licentiatura Thesis, Universidad Mayor de San Andrés.

21. Ponce Sangines C (1961) Report of Work. La Paz: Center for Archaeological Investigations at Tiwanaku, Tiwanaku: Space, Time and Culture: Test Synthesis.

22. Janusek JW (2003) The Changing Face of Tiwanaku Residential Life: State and Social Identity in an Andean City. In Tiwanaku and Its Hinterland: Archaeology and Paleoecology of an Andean Civilization, Washington, D.C.: Smithsonian Institution Press 2: 264-295.

23. Janusek JW (2004) Identity and Power in the Ancient Andes: Tiwanaku Cities through Time. Routledge Press, London, UK.

24. Flow Science (2012) Flow-3D User Manual V 9.3. Flow Science, Inc Santa $\mathrm{Fe}, \mathrm{NM}$.
25. Bear J (1972) Dynamics of Fluids in Porous Media. Dover Publications, New York.

26. Freeze RA, Cherry JA (1979) Groundwater. Englewood Cliffs, NJ: PrenticeHall, Inc.

27. Peck RB, Hanson WE, Thornton TH (1974) Foundation Engineering. New York: John Wiley and Sons.

28. Kolata LA (1996) Tiwanaku and its Hinterland: Archaeology and Paleoecology of an Andean Civilization. Smithsonian Institution Press, Washington D.C, USA

29. Vallières C (2012) A Taste of Tiwanaku: Daily Life in an Ancient Andean Urban Center as Seen through Cuisine. Ph.D Thesis, Department of Anthropology, McGill University, Montreal, Canada.

30. Ortloff CR (2009) Water Engineering in the Ancient World: Archaeological and Climate Perspectives on Societies of South America, the Middle East and South East Asia. Oxford University Press, USA. 